\title{
The Use of Modal Auxiliary Verbs among Selected Pre-Service Students at A South African Rural University
}

\author{
Monica Dudu Luvuno ${ }^{1} \&$ Oluwatoyin Ayodele Ajani ${ }^{2}$ \\ ${ }^{1}$ Professional Teaching Practice, University of Zululand, South Africa. E-mail: LuvunoM@unizulu.ac.za \\ ${ }^{2}$ Social Sciences Education, University of Zululand, South Africa. E-mail: oaajani@gmail.com \\ Correspondence: Oluwatoyin Ayodele Ajani, Social Sciences Education, University of Zululand, South Africa.
}

Received: August 1, 2021

Accepted: September 17, 2021

Online Published: September 18, 2021

doi:10.5430/ijhe.v11n2p67

URL: https://doi.org/10.5430/ijhe.v11n2p67

\begin{abstract}
This study was conducted at a university based in KwaZulu-Natal, South Africa. The purpose of the study was to determine if the explicit instruction of selected grammar aspect, modal auxiliary verbs, improved students' ability to write English. The study was qualitative in nature and a case study design was adopted. The focus was in relation to a sample of 80 student teachers who were randomly selected in 2016 in the Faculty of Education. 40 participants were randomly assigned into experimental and control groups. For the experimental group, training lasted six weeks. Both groups were made to write similar essays and those essays were marked focusing on the students' ability to use modal auxiliary verbs. The study's findings revealed that the experimental group performed better than those in the control group in the use of modal auxiliary verbs. Based on the findings, the study recommended explicit grammar instruction in all the students' level of study in order to overcome the challenges they have in writing English. Thus, time should be created to ascertain that adequate explicit grammar lessons are offered to all pre-service teachers at the university.
\end{abstract}

Keywords: modal auxiliary verbs, explicit teaching, grammar, pre-service teachers, written work, English second language

\section{Introduction}

In South Africa, during the apartheid era, the standard in academia was the use of English and/ or Afrikaans as mediums of instruction at the universities for all students. After 1994 the situation changed as part of transformation in South Africa, with the inclusion of other languages that are South African official languages, such as IsiZulu, IsiXhosa, Tswana, Sepedi Sotho, etc. Thus, historically, the English language was predominantly adopted in African countries, where the Colonial masters were British. In education systems, English language became not only the language of communication and instruction but was also considered a language of economic advancement globally. English as a global language was and still is considered an asset and is often associated with higher employability and thought to be more advantageous than other languages (Moyo, 2020). Thus, lack of competence in the English language may sometimes restrict some people from being employed where only the English language is the medium of communication (Ajani \& Gamede, 2020). By implication, therefore, it is necessary for students to be prepared in reading and writing conventions of English language, alongside other indigenous languages, to provide them with employability opportunities when such chances become available. It is against this backdrop, that students must be well prepared to understand and use appropriately all the parts of speech in the language, most especially the use of verbs in speech and also in their written academic discourse (Moyo, 2012).

It has been established that the teaching of modal auxiliary verbs at university can help students use various modal auxiliary verbs competently in their writing (Ngoinjuguna, 2018). Thus, student teachers at the university should be critically engaged with various activities to enhance their knowledge of modal auxiliary verbs and how these modal auxiliary verbs are correctly used in their writing. In language classes, ESL teachers need to deal with these grammar units to equip students with the knowledge that they need and should assess students' written work in terms of clarity of expression and grammatical accuracy over and above the subject content in order to help students improve the way they convey their messages specifically in writing.

It is also notable that although ESL pre-teachers, who are still undergoing teacher training are expected to acquire adequate competencies in their command of English in both spoken and written modes, before the completion of 
their study at Year Level 4, of their professional teacher training programme (Singh, et al 2017). This study explored the use of modal auxiliary verbs in written texts among the undergraduate students in a rural university. Various studies have examined problems encountered by ESL pre-service teachers on the modal auxiliary verbs to improve their own academic writing (Moyo, 2012; 2020). The aim of this study is to further explore the challenge faced by ESL university pre-service teachers, learning how to teach and use modal auxiliary verbs in their academic writing. The findings of the study will assist stakeholders in the system to draw intervention for these students.

\subsection{Theoretical Frameworks}

Creating and shaping meaning in written form has always been an onerous task for most ESL students at a university setting. As argued by Imenda (2014), Fain (2004) and Green (2014), there is no single theory in qualitative research which one can meaningfully use to address a specific research problem, to the exclusion of other competent theories. On the contrary, small individual pieces, called concepts, are conveniently joined with the view of coming up with a conceptual framework or model towards providing a bigger picture of possible existing relationships. Hence, Imenda (2014) avers that a conceptual framework is an integrated way of addressing a research problem which is drawn not from one theory or source but from many sources. It is for this reason, therefore, that this article is premised on the following four theories:
(a) Constituent Structure Analysis.
(b) Krashen's (1987) Input Hypothesis Theory.
(c) Long's (1991) Form-Focused Instruction (FFI); and
(d) Ellis' (1994) Focus-on-Forms Instruction.

\subsection{Constituent Structure Analysis}

Constituent structure analysis is a framework that breaks the reading of texts with complex structures into smaller pieces or concepts, and thus enhances the comprehensibility of written texts (Waudhaugh, 2002). Hedge ( 1996); Akmajian (1995); Waudhaugh (2002) opine that there are benefits that accrue from recognising and applying constituent structure, as it greatly helps not only in constructing but also in analysing sentences, to elucidate their complexity. Similarly, Wardhaugh (2002) further asserts that whenever we put words together to form multiword utterances or sentences, we must do so in a systematic fashion, which refer to only certain kinds of arrangement or structures called syntactic structures that are possible and that these structures are used over and over again in construction of written texts. The structure of a construction necessarily involves identifying its constituents (Wasserman, 2019), and as such one important property of a sentence is its communicative potential; and sentences with different structures, have different communicative functions (Akmajian, 1995). Hence, the rationale for this theory is its ability to help students structure their sentences with appropriate modal auxiliary verbs.

\subsection{Input Hypothesis}

In Krashen's (1987) view, learners learn a language better if they are exposed to adequate comprehensible input which is appropriate for meaningful expression. Instead of using the term 'comprehensible input', Krashen uses 'intake' in his early writings by which he means that subset of linguistic input that helps the acquirer learn the language (McLaughlin, 1987: 39). Intake or comprehensible input is the use of appropriate words or phrases that provides intended meaning and, are understood by the learner. McLaughlin (1987:39) further argues that overall output contains language structures that are a bit beyond the syntactic complexity of those found in the current grammar of the acquirer. Hence, it is recommended that students be engaged in language programmes that immerse them to numerous linguistic structures for them to develop the requisite grammar that they need at any given time (McLaughlin, 1987).

\subsection{Form-Focused Instruction (FFI)}

Long (1991) contends that Focus on Form Instruction (FFI), especially of the more explicit kind, is necessary to promote effective language learning. FFI theory further indicates that grammar has to be taught explicitly as in the Grammar Translation Method. According to Long (1991), in focus-on-form, language is broken down into discrete elements, such as words, grammar rules, notions, functions, which are then taught item by item in a linear, additive fashion. Long (1991:22) thus observes that systematic or structured input involves three types of processes:
(a) Intake
(b) Acquisition and
(c) Production 
Long (1991) is of the view that the process of intake takes place when students are noticing forms in the input and storing them in short-term memory. To this end, acquisition is the incorporation of those new forms in long-term memory and the restructuring of the inter language systems which impacts on language production which is the use of stored forms in writing or speech (Long, 1991). However, Long (1991), and Moyo (2020) argue that exposing students to enough comprehensive input alone is inadequate; that students must also be given opportunities to produce new forms learnt from spoken or written exercises or both to develop their own input.

\subsection{Focus-on-Forms Instruction}

According to Ellis (2006), there are three types of Focus on Forms Instruction which need to be used in language teaching. The first type is Focus-on-Forms, focusing primarily on linguistic form with the second type being Planned Focus-on-Form which focuses primarily on meaning and the third type is Incidental Focus-on-Form which concerns itself with form only in the event of a problem arising. In this article, the researcher adopted Ellis' Type 1: Focus-on-Forms Instruction to strengthen the study. This Focus-on-forms Instruction promotes explicit teaching of modal auxiliary verbs, which likely play a significant role in addressing the problem under investigation. Focus-on-forms, in Ellis's point of view, implies that the teacher and the students are aware that their primary focus of the activity is to learn a preselected form and that students are required to focus on some specific form intensively with the view of learning them. This concurs with Long's (1991) view that Focus-on-forms constitutes a traditional approach to language teaching involving a linear syllabus, instructional materials, and corresponding procedures designed to present and practice a series of linguistic items. In this type of instruction, students' primary attention is directed at a specific linguistic form without necessarily excluding meaning. Explicit focus-on-form, as Ellis (2006: 17) describes it, "is the instruction that involves rule taught during the learning process". Even those who oppose this view of the rule being taught, like Krashen (1987), agree that in writing, writers have time to monitor and to apply knowledge from learned rules.

With regard to approach, Ellis (2006) argues that the rule can be taught explicitly or implicitly. Thus, while on the one hand, deductive presentation entails presenting the rule to students in the classroom situation, an inductive or discovery treatment, on the other hand, steers students towards coming up with a rule themselves through analysing data typifying the language aspects that are being taught. This occurs, for example, in instances where students have to identify the rules that are demonstrated by the specific set of sentences. In such a case, Ellis contends that students function as learners rather than users of the language thus treating language as an object to be studied and practised bit by bit. This, in Ellis' (1994) view, is an onerous task since attending to form and meaning at the same time is not an easy thing to do. It is arguable, therefore, that explicit learning contrasts with implicit learning in that in explicit learning, students are aware of what they are learning (Ellis, 1994). In the light of this, therefore, it cannot be gainsaid that experimental systems are ideal for language learning because they involve drilling students in the production of the target form and also allows correction of the students' errors in the process.

Notably, errors are mistakes which students cannot correct without help (Chkotua, 2012). Thus, it can be contended that when students are drilled with relevant units of language, they stand a better chance of becoming aware of the target structure in their attempt to construct a conscious rule (Ellis, 2006). Many concerned teachers, like the researcher, are of the view that helping students to improve the competency of their writing is vitally important. However, there is an inconclusive debate over the effectiveness of teacher feedback on learner writing errors by Truscott (1996) and Ferris (1999). Truscott (1996) advocates for the abolition of grammar correction in writing courses as he deems it ineffective. Truscott (1996), Ferris (1999) aver that research evidence has shown that effective error correction which is selective, prioritized, and clear-can can help some student writers.

\section{Literature Review}

Proficiency in any language is evidently shown in the use of the language for communication. Hence, proficiency of the language revolves around the spoken and the written use of the language in communication (Webb et al, 2000). Being able to communicate effectively in a language such as English, presupposes at least the following types of communicative knowledge:

(a) Grammatical competence which entails knowing how to combine the units of a language into grammatical wholes (words or sentences).

(b) Textual competence which entails knowing how to combine sentences into effective texts or conversations / discourses.

(c) Pragmatic competence which is the ability to use language to perform a chosen function, as well as the ability to select the appropriate way of speaking in specific situations. 
(d) Strategic competence is the ability to manipulate linguistic forms to achieve one's communicative function.

It can be gleaned from the explication of the different types of communicative knowledge above that the resultant focus in the context of student teachers' writing is on the other forms of knowledge beyond grammatical competence. The students in teacher education need in-depth understanding of grammar in English language for effective use and clarity in language of learning and teaching. In the context of these pre-service teachers, foregrounding specific language structures such as the Modal Auxiliary Verbs in the construction of sentences, which can be a viable pragmatic approach geared towards enhancing the acquisition and proper use of the target language by prospective users such as student teachers.

\section{What Modal Auxiliary Verbs are}

Baldeh (2001) describes modals as verbs that are used with other verbs to make a change in meaning. This to him posit the use of modal auxiliary verbs as imprecise. Further clarification to this is, the use of various modal verbs to give the ideas of possibility, impossibility, necessity, willingness, certainty, uncertainty and expectation. While Eyisi (2011) identifies nine types of modal auxiliary verbs as: can/could, may/might, shall/should, will/would, must. Furthermore, Halliday (2004) rightly points out that the grammar and the semantics of modal auxiliary verbs in native English are of concern to scholars from a long time. Umeh and Anyanwu (2020:3) argue that "modal auxiliary verbs pose a complex problem as far as linguistic description is concerned. Classifying modal auxiliary verbs is by no means unproblematic, since individual modals may function in more than one category". Baldeh (2001) in his own argument, explains that can/may convey possibility in the sentence as revealed in examples such as: Even doctors can make mistakes; may convey characteristics in the sentence: You can be stubborn at times; sensation in the sentence: I can hear you from the back of the class; and willingness in the sentence: Can you call met, please? Modal auxiliary verbs can cause multiplicity of meanings that could be derived from a particular modal verb, Branford (1967) emphasizes that "it is possibly better to avoid labeling any modal too specifically (e.g. can = ability)."

Modal auxiliary verbs are simply called helping or supporting verbs (Oxford Advanced Learners Dictionary of current English, 1995). They are called so because of the supporting functions to other verbs in communication (Alagbe, 2009). Quick et al, (1998: 129) and Oluwole \& Rose (1996: 157) contend that the fact that modal auxiliary verbs co-occur in a verbal group in a sentence is what earns them the name 'helping verbs'. According to Wardhaugh (2002:19), 'any misuse or omission of auxiliary verbs in focus, distorts messages' meant to be sent and 'modal verbs are complicated in the kinds of meanings that they express'.

Palmer (2003:14) further argues that 'modal auxiliary verbs cannot co-occur since they have no non-finite forms and are restricted to the initial position in the verb phrase. This means that in the English language, there is no 'can may' go or 'must can may' go.

Kroeger (2005) views that the behaviour of some modal auxiliaries might bring about faulty grammar which can lead to genuine ambiguity, can be a barrier to communication, and can hinder students' success in their educational pursuits.

Similar sentiments are expressed by Praninskas (1959) who refers to modal auxiliaries as the ten words (can, could, may, might, must, ought, shall, should, will, and would) in the English language that give students just about ten times as much trouble compared to other words. In Praninskas' (1959)'s view, despite being verbs, modal auxiliaries do not function alone like complete verbs unless used to answer certain questions. Characteristically, therefore, modal verbs are used with other verbs to modify meaning. They do not use 's', '-ing' forms or participles. This means that modal auxiliaries with 's' are not transformed.

Crystal (2011: 33) construes 'modal auxiliary verbs' as a term used in the grammatical description of the verb phrase to refer to the set of verbs which are subordinate to the main lexical verb and thus help to make distinctions in mood, aspect, and voice. The modal auxiliaries together with past tense forms include 'can'/'could', 'may'/'might', 'shall'/'should', 'will'/'would', 'must', and also 'ought to' and 'used to' (Coetzee-Van Rooy, 2020). Crystal (2011: 34) also cites 'marginal' or 'semi-auxiliaries' as verbs which display some but not all properties of the modal auxiliary verbs such as 'dare' and 'need'. Praninskas (1959) and Cummins (1997) suggested that in order to be able to use modal auxiliaries competently, one needs to find various sentences where they are used and be certain that one understands what they mean in their different contexts. For example, modal auxiliary 'could' sometimes function as the past form of 'can', 'would' and 'will'. Those past forms can be used to mark present and future times respectively. 


\section{The difference between primary and secondary auxiliary verbs}

According to Alagbe (2009:57), modal auxiliary verbs (secondary) are different from the primary auxiliary verbs in that modals cannot not stand on their own in a sentence as it is the case with the lexical verbs in a sentence but play a vital role in conveying error-free and meaningful information to readers. In Alagbe's view, 'modal auxiliary verbs are used along with lexical verbs'. For example:
(a) He can go.
(b) We should do that.
(c) You must go'.

According to Alagbe (2009: 56), modal auxiliaries help to make up the verbal group in sentences, which means that they support the main verbs which can either be transitive or intransitive. This is also meant to help communicate meaningfully in sentences where they are used. According to Thompson and Martinet (1987b: 110), modal auxiliaries have no final ' $s$ ' in the third person singular, and they do not have a past tense. Similarly, Palmer (1994:122) argues that 'only the primary auxiliary verbs have -s forms: is, has and does' as there are no modal forms like 'wills', 'shalls', 'cans', 'mays', 'musts' and 'oughts'.

\section{Concern with ESL university student language proficiency}

Education is one of the areas where English plays a dominant role in many parts of the world. It is in light of this, therefore, that in many countries, including South Africa, English is an official language. Hence, schools and institutions of higher learning in South Africa use English as a medium of instruction which is officially known as the language of teaching and learning (LoLT). Barnes (2011) and Cumming (1997) are of the view that those who want to access and use world knowledge need to not only have a good understanding of the language, but also need to be proficient in the language. It is thus arguable that the starting point in understanding any language is to know its structure. According to Biber, Conrad and Leech 2010:48) the English structure consists of the noun phrase, the verb phrase, adjectival phrase and prepositional phrase.

\section{Teaching Grammar to university students}

Many researchers (Hudson 1991; Thompson \& Martinet 1987a; Biber, et al 2000; Alagbe 2009; and Crystal 2011) cite the importance of teaching grammar to the university students for these students to gain language proficiency. Moreover, Alobo (2015) avers that it is appalling and embarrassing to read students' essays at the tertiary level today given the gross misuse and abuse of the language. However, during the period the study was undertaken, it was evident that even though some researchers (Wasserman, 2019; Coetzee-Van Rooy, 2020) have written about auxiliary verbs, none of them concentrate on the importance of teaching and use of modal auxiliary verbs by ESL students to help them write competently at the university level in particular. Antia and van der Merwe (2019) opine that teaching and learning of Grammar in the universities is important to communication development of students, and the underatnding of the grammatical structures of English language influence the students' language proficiencies and competencies.

\section{Students' Problems in Using Modal Auxiliary Verbs}

As useful as modal verbs are in writing, they are not easy to teach or to use appropriately for non-native speakers of English (Gibbs, 1990) because of their underlying meaning (Cook, 1978). Many students are disadvantaged by the fact that they have to learn through a second language rather than their home language. Modal auxiliaries' usage presents inherent difficulties even among first language speakers of English, which renders appropriateness of modal auxiliary use crucial for communication (Ngoirinjuguna, 2018). MAVs do not have a one-to-one relationship with meaning (Holmes, 1988). Some students, who are ESL users find it confusing that one modal auxiliary verb might have several meanings or functions (Thompson \& Martinet 1987b; Parrot 2010; Biber et al 2010). Moreover, students who are ESL users have problems in deciding when to use modal auxiliary verbs and which ones to use. The teaching of these language forms will not only equip students with the necessary skills to improve their written work but will also provide them with the requisite knowledge of how modal auxiliary verbs work in the English clause. This in turn, will help students understand different texts better.

Notably, Ayliff (2010:2) argues two crucial reasons why most ESL students fail to be proficient in the use of English language due to many reasons. Ayliff (2010) opines that Outcomes-based Education (OBE) which encourages a learner-centred approach to education is one of the reasons for students' failure to attain proficiency in English. According to him, this approach stipulates that students should be placed in situations where they use the language as an instrument for satisfying immediate communication needs, and where the criterion for successful communication 
is functional effectiveness rather than structural accuracy. The ultimate concern is in developing the learners' ability to take part in the process of communicating through language, rather than with the perfect mastery of individual structures such as using the modal auxiliary verbs competently in speaking and writing. As far as the theory of OBE is concerned, grammar is learned in passing only to understand the activity at hand and through self-discovery. Thus, there are no drills or complete explanations and understanding of language structures.

Another reason for lack of proficiency according to Aliff's (2010:3) view, is the way the English language is taught through a communicative meaning-based approach introduced by the National Curriculum Statement (NCS) which later became known as CAPS in the South African schools. Dornbrack and Jacqui (2014) observe that CAPS overemphasis of a 'back to basics' discourse undermines creative writing whereas these researchers view it as an important product from which students are judged. In this approach students' lessons concentrate on meaning hoping that they will unconsciously get grammar of the language along the way. This is based on the misguided understanding that students learn the second language the same way as they learn their first language where' $a$ child effortlessly picks it up the language from the family members and people around his or her world. The teacher supports the student as she or he takes control of his or her learning by bringing activities which model the real world into the classroom. This approach to learning helps students to become confident and fluent in the language, but it is unlikely that it makes them write with accuracy. Students find writing essays, for example, quite challenging due to the lack of explicit instruction on how language works in language classrooms (Dornbrack \& Jacqui, 2014). According to Hudson and Walmsley (2005:612), time should be devoted to administer adequate grammar lessons to students even at the university level.

\section{Methodology}

\subsection{Research Design}

The study adopted a qualitative approach to explore students' understanding of the phenomenon (Seliger \& Shohamy, 1980). Moreover, Halliday (2002) contents that qualitative studies offer opportunities of research that lead researchers into areas of discovery within the lives of people they are investigating. The study also used a case study design. According to Michael (2005), a case study design allows researchers to focus on a single case mainly for scrupulousness and comprehensive understanding. Therefore, the qualitative method was deemed appropriate for this study because it allowed the study to understand and explain arguments envisaged in the study using in depth evidence collected directly from the real classroom situations through students' written essays conducted at the lecture hall at the University of Zululand.

\subsection{Participants}

The sample was selected based on convenience sampling as they were accessible to the researcher. The participants in this study were 80 students doing level four in the Faculty of Education at the University of Zululand. Of the 80 participants, 40 were assigned to an experimental group and the other 40 to a control group. All the participants gave their consent to take part in the study. The experimental group was taught modal auxiliary verbs for six weeks by the researcher. The control group was not taught any of the modal auxiliaries. The study is operationally oriented as it was actioned in real class room in the lecture hall at the University of Zululand. The instance actioned here was done to establish whether the teaching of this particular item can help students improve their academic writing. At the end of six weeks, both groups, the experimental group and control group were made to write similar essays in class.

\subsection{Instrument}

In order to shed light on the degree of Modal Auxiliary Verbs challenges faced by ESL students at the University, the students' written essays served as an instrument to solicit data. Two groups of students, 40 each, were asked to write essays of about one-and a-half pages on their chosen topic. Essays had six topics for the students to choose one from. Six different essay topics assumed to have been within the cognitive and linguistic level. According to Sasaki and Hirose (1996), when students are engaged in essay writing, they learn to present a standpoint, to generate, select and arrange arguments to support their point of view and to integrate these elements in a rhetorically attractive text. The essays also provided adequate information on modal auxiliary verbs students had mastered and which ones they were still struggling with since, in English, there are quite a number. Additionally, the essays showed which modal auxiliary verbs had been repeated because unnecessary repetition of modal auxiliary verbs can hinder communication. They also gave students the opportunity to express themselves in writing. Instead of interviewing students, therefore, the researcher had both groups write essays. The essays were rated and compared against each other to see if there were measurable differences between the two groups. 


\subsection{Data Analysis}

Students' essays were analysed using qualitative content analysis. Content analysis is a detailed and systematic examination of the contents of a specific body of material for purposes of identifying patterns, themes or biases within that material (Maree, 2007). Thus, in line with the concept of constituent structure analysis, the focus of the analysis was on the structural positioning of the modal verb in relation to the head verb within the predicate verb phrase of each sentence. The analysis of the sentences foregrounds the Aux VP structure in each sentence.

In order to assign an overall score for students' performance which was out of 50, marks were distributed according to three aspects: content and planning of the essay (32 marks), grammar and editing (12 marks), and the structure (6 marks) as it is shown in the marking rubric (see Appendix 1). In Bachman and Palmer (1996) are of the view that broad specifications be used to define the criteria by which the quality of the essays is evaluated. To indicate how well each student fitted in a category, while reading and marking students' essays, the researcher underlined all Modal Auxiliary verbs found in sentences of each essay.

\subsection{Findings from Data Analysis}

Using constituent structure analysis (Aux VP) on the data as it obtains in sections B1, B2, C1, C2, D1, D2, E1, E2, F1, F2, G1 and G2 respectively derived from both the control group and the experimental group it was established that students needed to be taught the basic sentence structure and other language units in order for them not only to write grammatical sentences but also to engage themselves with meaningful written discourse. As the focus of the analysis was on the structural positioning of the modal auxiliary and the meaning it attaches to the lexical verb of the predicate verb phrase, it was established that student teachers displayed minimal knowledge of the structural positioning of the modal auxiliary verb and how its presence or absence impacts on the resultant meaning of the lexical verbs.

\subsection{The Experimental Group}

The experimental group demonstrated significant productive knowledge of modal auxiliary verbs in their written work as is demonstrated in the table below:-

Table 1. Use of Modal Auxiliary Verbs by Experimental Group

\begin{tabular}{lllll}
\hline Mod Aux Verbs & Topics $(\mathbf{N})$ & Sum & Mean & Std. Deviation \\
\hline Can & 6 & 35,00 & 5,00 & 3,42 \\
Could & 6 & 11,00 & 1,57 & 1,51 \\
Shall & 6 & 0,00 & 0,00 & 0,00 \\
Should & 6 & 4,00 & 0,57 & 0,79 \\
Will & 6 & 30,00 & 4,29 & 3,50 \\
Would & 6 & 7,00 & 1,00 & 0,82 \\
May & 6 & 15,00 & 2,14 & 2,41 \\
Might & 6 & 0,00 & 0,00 & 0,00 \\
Must & 6 & 6,00 & 0,86 & 0,90 \\
Ought to & 6 & 0,00 & 0,00 & 0,00
\end{tabular}

In Table 1 above, the mean and variance of participants who used the selected modal auxiliary verbs in their choice of topics are shown. From the seven topics that participants were to choose from, none used the modal auxiliary verbs "shall" and "ought to" among the experimental group, even though these modals were taught in class. The modal auxiliary verbs that recorded significantly low mean and standard deviation are; "dare" with a mean of 0.14 and standard deviation (0.38); "used to" (0.43 and 0.53$)$; "should" (0.57 and 0.79$)$; and "must" (0.86 and 0.90$)$. There is, however, a significantly large deviation in the use of the verbs "can" and "will" among the experimental group with a recorded mean and standard deviation of $(5.00,3.42)$ and $(4.29,3.50)$ respectively. A significantly lower mean deviation demonstrates that majority of the participants who wrote essays on the seven topics had challenges in using the semi-modal auxiliary verbs: 'dare' and 'used to'. There was heterogeneity in how participants used the modal verbs 'can' and 'will' in the essays they selected to write on. This explains why the average use of these verbs has recorded a significantly large variance. Although it was hypothesised that there would be a 
significant variation in the average use of modal auxiliary verbs between the experimental and control groups, the average and variances are relatively low among the control group as shown in Table 1.1 above.

\subsection{The Control Group}

The control group, on the other hand, demonstrated minimal knowledge of modal auxiliary verb use and therefore, used no or very few modal auxiliary verbs in their essays as it is shown in Table 2.1 below:

Table 2. Use of Modal Auxiliary Verbs by the Control Group

\begin{tabular}{lllll}
\hline Mod Aux Verbs & Topic $(\mathbf{N})$ & Sum & Mean & Std. Deviation \\
\hline Can & 6 & 18,00 & 2,57 & 2,70 \\
Could & 6 & 3,00 & 0,43 & 0,79 \\
Shall & 6 & 0,00 & 0,00 & 0,00 \\
Should & 6 & 4,00 & 0,57 & 1,13 \\
Will & 6 & 15,00 & 2,14 & 2,27 \\
Would & 6 & 5,00 & 0,71 & 1,11 \\
May & 6 & 2,00 & 0,29 & 0,49 \\
Might & 6 & 1,00 & 0,14 & 0,38 \\
Must & 6 & 2,00 & 0,29 & 0,49 \\
Ought to & 6 & 0,00 & 0,00 & 0,00 \\
\hline
\end{tabular}

In Table 2 above, the use of modal auxiliary verbs among participants in the control group shows on average very low deviations. Assessment of essays from the control group revealed the use of modal auxiliary verbs 'could' and 'will' common, and thus scored a relatively large mean $(2.57,2.14)$ and standard deviation $(2.70,2.27)$ in both verbs respectively. This pattern was similar in among participants in the experimental group despite having slightly larger mean differences that are attributed to exposure to teaching. The modal auxiliary verbs 'shall' and 'ought to' was neither used by the control group as their counterpart in the experimental group. The modal auxiliary verbs: 'might', 'dare', 'must', 'may' and 'could' was commonly used by the control group in their essays and this explains the low mean deviation.

In order to get a better picture on how the two groups performed, it was also essential to further highlight errors of these groups by using Error Analysis. Error Analysis (EA) in second language acquisition was established in the 1970s by Corder and his colleagues. Together, they described EA as a type of linguistic study that focuses on the errors that students make in communication, whether written or verbal. They agreed that making errors in learning a language is necessary and vital as without it no desired improvement can occur in students' competence. EA researchers observed that errors are advantageous for both students and teachers as they provide valuable information to the teachers on students' errors. This assists the teachers to identify persistent errors that students make, to correct and to improve their own teaching by focusing on those critical areas that need more attention (Corder 1967, Corder 1974, Crystal 2011, Welreesh 1991, Vahdatinejad 2008, Selinker 1972).

The analysis of students' written essays will be derived from Corder's (1967) three stages of error analysis which are the identification of error, classification of error and explanation of error. The following table is the representation of the errors that were found in students' essays according to these stages: 
Table 3. Error analysis of the control group

\begin{tabular}{|c|c|c|}
\hline Identification of error & Classification of error & Explanation of error \\
\hline $\begin{array}{l}\text { Failure will prepares you to face } \\
\text { every situation. }\end{array}$ & Wrong use of modal & $\begin{array}{l}\text { Failure will prepare you to face } \\
\text { every situation. }\end{array}$ \\
\hline $\begin{array}{l}\text { They need to put more effort so } \\
\text { that they will success. }\end{array}$ & $\begin{array}{l}\text { Lack of knowledge on how } \\
\text { modals are used }\end{array}$ & $\begin{array}{l}\text { They needed to put more effort so } \\
\text { that they will succeed. }\end{array}$ \\
\hline $\begin{array}{l}\text { I wish everybody start to suffer so } \\
\text { that they do everything to work } \\
\text { hard to achieve their goals. }\end{array}$ & Ambiguity & $\begin{array}{l}\text { I wish everybody could suffer so } \\
\text { that they could start to work } \\
\text { harder in order to achieve their } \\
\text { goals. }\end{array}$ \\
\hline $\begin{array}{l}\text { We turn to forget that we fail } \\
\text { because of procrastination. }\end{array}$ & Non-use & $\begin{array}{l}\text { We forget that we can fail due to } \\
\text { procrastination. }\end{array}$ \\
\hline $\begin{array}{l}\text { Through technology learners } \\
\text { understand a lesson. }\end{array}$ & Non-use & $\begin{array}{l}\text { Through technology learners are } \\
\text { able to understand a lesson. }\end{array}$ \\
\hline \multicolumn{3}{|c|}{ ble 4 . Other language errors of the control group } \\
\hline Identification of error & Classification of error & Explanation of errors \\
\hline $\begin{array}{l}\text { When life push you around, you } \\
\text { should push it back. }\end{array}$ & Verb form & $\begin{array}{l}\text { Wrong tense/inappropriate verb } \\
\text { construction }\end{array}$ \\
\hline $\begin{array}{l}\text { The quality of education keep on } \\
\text { increasing, }\end{array}$ & Subject verb agreement & Subject singular, verb plural \\
\hline $\begin{array}{l}\text { We are coming in a different } \\
\text { background where there is no } \\
\text { radio. }\end{array}$ & Preposition & Wrong preposition \\
\hline Teachers they use technology. & Reference error & $\begin{array}{l}\text { Wrong pronoun/demonstrative } \\
\text { determiners to use }\end{array}$ \\
\hline This is a weikup call. & Word form & Incorrect spelling of words \\
\hline $\begin{array}{l}\text { She realise that she need to put } \\
\text { more effort... }\end{array}$ & Past tense form & $\begin{array}{l}\text { She realized that she needed to } \\
\text { put more effort... }\end{array}$ \\
\hline $\begin{array}{l}\text { You cann't live the life you } \\
\text { wanna live. }\end{array}$ & Wrong word form & $\begin{array}{l}\text { You can't live the life you want to } \\
\text { live }\end{array}$ \\
\hline $\begin{array}{l}\text { Boys usually they like to play } \\
\text { soccer ball. }\end{array}$ & Pronoun & Wrong use of the pronoun \\
\hline
\end{tabular}

No errors of failing to use modal auxiliary verbs correctly were identified in the experimental group. However, there were errors of spelling and of students not proofreading their work before submissions that were evident on both groups as it is displayed in the table below: 
Table 5. Errors identified on both the experimental and the control groups

\begin{tabular}{|c|c|c|}
\hline Identification of error & Classification of error & Explanation of error \\
\hline $\begin{array}{l}\text { You would not repeate the same } \\
\text { mistakes istead you would fight to } \\
\text { become a better person. }\end{array}$ & Proofreading & $\begin{array}{l}\text { You would not repeat the same } \\
\text { mistakes instead you would fight to } \\
\text { become a better person. }\end{array}$ \\
\hline $\begin{array}{l}\text { Sport can unite or devide the } \\
\text { nation. }\end{array}$ & Carelessness & Sport can unite or divide the nation. \\
\hline $\begin{array}{l}\text { She isn't the one who provides the } \\
\text { required information. }\end{array}$ & Informal usage & Contractions, informal vocabulary \\
\hline $\begin{array}{l}\text { To failure is for everybody you } \\
\text { need to failure before you reach } \\
\text { something better in life. }\end{array}$ & Run-on sentence & $\begin{array}{l}\text { To fail is for everybody. One needs to } \\
\text { fail before one obtains something better } \\
\text { in life. }\end{array}$ \\
\hline I experience a lot of things. & Tense & I experienced a lot of things. \\
\hline When I goes around the world. & Concord & When I go around the world. \\
\hline
\end{tabular}

It was surprising though that students were failing to write the word 'divide' correctly yet the word was in the topic that they chose to write on. It displayed the high level of carelessness when it comes to students' written work.

Findings indicated that some of the students used modal auxiliary verbs in their essays and presented their ideas more effectively while some of the students used few or no modals effectively. The majority of those who did not use modals at all, experienced serious problems of producing essays of poor quality with glaring grammatical errors. The majority of the teacher students failed to position the modal auxiliary in its structural position as dictated to the basic sentence structure in English.

\section{Discussion of Findings}

What has emerged from this study as derived from the literature reviewed and the analysis of the data from the respondents' written essays showed that the teaching of modal auxiliary verbs at the university can enhance students' use of grammar competently in their writing. Thus, the argument advanced in this regard is that if second language users of English know its grammatical structure in its use of modal auxiliary verbs in sentences, prospects of enhancing the communication of ideas as intended are huge. According to Foppoli (2012) and Corder (1978) grammar is the foundation of language learning for second language students. So, it is important to underline the fact that such knowledge of the use of these grammatical units has the potential of helping ESL students articulate their ideas precisely and succinctly in writing (Wasserman, 2019). Through detailed studies of student writing, Shaughnessy (1977) concludes that the best grammar instruction is that which gives the greatest return for the investment of time. In another related study, Matshotsho and Cekiso (2015) further revealed that the students may be able to write well if they are exposed to a variety of genres of writing including flyers, magazines, papers and books, amongst others. Therefore, Coetzee-Van Rooy (2020) affirms that more time should be allocated to expose students to explicit grammar lessons at the university.

It is important also to note from the findings that teachers of ESL teachers need to be highly competent (Royce 1996; Crystal 2011; Ngoirinjuguna 2018) in teaching and using modal auxiliary verbs, to assist students' attainment of competence that is required by schools. This concurs with the literature (Baleghizader \& Gordani 2012; Shaw \& Liu 1998) where mastering English grammar for ESL students had been observed essential for them to achieve their educational, professional and even personal goals. In addition, Moses and Mohamad (2019) argue that news websites, social media marketing corporations and other related and non-related IT corporations need good writers to help them through writing for digital marketing channels such as brand quotes, advertisement, social media posts, and blogs. Therefore, in language classes, ESL teachers need to deal with these grammar units to equip students with the knowledge that they need and should assess students' written work in terms of clarity of expression and grammatical accuracy over and above the subject content in order to help students improve the way they convey their messages specifically in writing.

Eyisi (2011) asserts that modal auxiliary verbs are indeed difficult and their appropriate use present difficulties in students' written work. Most English second language students at the University fail to express themselves correctly in writing:

(a) English is a second language for a majority of them. In their study, Myles (2002) and Singh (2017) observed that students' inability to write well is believed to be due to the influence of their mother tongue and also 
insufficient knowledge of grammatical rules and concepts. Their findings revealed that many students are disadvantaged by the fact that they have to learn through a second language rather than their home language. Because of this, the students have the tendency to translate from their first language while writing.

(b) Students are not given adequate grammar lessons, as lecturers believe that through reading, listening, speaking and using the language over a period of four years of study, students will automatically acquire grammar accuracy in writing, which does not turn out to be true (Hudson and Walmsley, 2005). The results of the study conducted by Selvaraj and Azlina (2021) show that with little knowledge in grammar, students will face difficulty in writing correct sentences.

(c) Minimal use of English language outside lecture halls. A small amount of time allocated to the teaching of English grammar will not give lecturers sufficient focus on 'serious in-depth teaching of grammar' to students to make up for the language gap that they have. Explicit attention to grammatical structures such as modal verbs can deepen ESL students' understanding of the language structure and its register which is why Dornbrack and Jacqui (2014) call for a more explicit focus on writing pedagogy.

As a result, ESL students misuse or do not use small but vital grammar units such as modal auxiliary verbs which leads to not communicating their ideas as clearly and concisely as they intend to, particularly in writing. A similar observation was made by Mohtar et al (2017) wherein he emphasised that students often display weaknesses in their written work; these weaknesses are seen in the structures they produce and also in the ideas expressed. They do not know which modal auxiliary verbs to use, when to use them and how to use them (Chin, 2000). Yet modal verbs misuse or omission

- $\quad$ interfere mostly with meaning

- could lead to ambiguity

- and could be a barrier to communication.

The study set out to establish and adopt an approach which can assist English second language students to use modal auxiliary verbs competently most especially in their academic writing. The expected results of the study after the experimental group had been taught was that such teaching would help towards:

- enhancing effective communication of their ideas as intended.

- enabling students articulate their ideas precisely and succinctly in writing

- achieving clarity

\subsection{The Experimental Group}

This study also revealed that there were no sentences that were identified by the researcher where respondents in the group, misused modal auxiliary verbs in their essays. Contrary to what was attested by Krashen (1987) that the teaching of grammar rules does not result to the acquisition of the target language, just because of the teaching on how modal auxiliary verbs work in a sentence to change the meaning helped the experimental group to use them effectively in their essays. It was difficult for the students to grasp all grammatical units which were used in a sentence from oral communication because most of the times we did not speak the same way as we wrote. This finding is echoed by Good (2002) who observed that in writing, the accuracy of grammar became key whereas in speaking one could get away with so many language mistakes. For example, Alyliff (2010) asserted that we could pronounce an English word correctly but do not know how to write it down correctly. This finding is in line with so many other examples like those of the findings of this study which were made by students which emphasized the fact that explicit teaching of grammar rules was necessary for students of English as a second language to become effective users of the language explicitly in writing. It was, therefore, necessary for ESL students to be clear with language features for them to fit them perfectly where they were supposed to be fitted (Good, 2002). If students understood that, it was likely that they will know where and when to use different modal auxiliary verbs in writing and other communication engagements.

\subsection{The Control Group}

There were some students who did not use any modal auxiliary verbs in their essay in the control group. However, according to the literature, 'any omission of modal auxiliary verbs in essay writing leads to distortion of messages' meant to be sent (Wardhaugh, 2002; Parkinson, 2001). Considering some students' responses, that observation proved to be true because apart from the noun phrase which was the central grammatical building blocks of a sentence, lexical verbs also played a significant role in conveying messages effectively particularly in writing. The 
non-use of modal auxiliary verbs by most students in the control group caused them not to convey their messages as clearly as they intended. That proved Algabe's (2009) argument to be valid that modal auxiliary verbs were sensitive words in a sentence that speakers of English could not ignore but needed to be used along with the lexical words so that accurate sentences could be produced. It was evident from the findings. Attesting to this reality, Zerin (2007), in his study observed that the skill of writing is considered as the most difficult task for students because they are not proficient in the language and do not have good mastery of grammar. They have limited exposure to the language and seldom communicate using the language in daily life. Therefore, good teachers of English should not allow the students to score high marks if their grammar was flawed in their written work because that was one of the reasons why we produced students who can speak the language but cannot write it, specifically at the university. The belief by Alyliff (2010) that 'every teacher is a language teacher' is a belief that resonated well with most of the language teachers because if we said that the emphasis on accuracy of language usage should focus only on students who were specializing in English, did we mean that it was acceptable for other students to graduate having not acquired the skill of using English language accurately particularly in writing?

\section{Conclusion}

Based on the results of research and discussion, the researcher sought to probe into the importance of explicit grammar teaching to student teachers at the university in all their levels of study irrespective of their specialisations. The reviewed literature revealed the implications of both teaching and not teaching English grammar to English second language students at the university. In the literature reviewed, it was also argued that the focus on teaching explicit grammatical forms in all year levels is the most effective approach towards improving meaningful grammatical competence of students. This can also help produce graduates who are not only better speakers of the English language but also good writers. The data collected from the student's written work revealed facts about struggles that they have not only with the use of modal auxiliary verbs but with other grammar units. The findings indicate that the grammar in students' work who are taught fairly well changes as a result of attending grammar lessons for a reasonable duration as they get to use modal auxiliary verbs frequently than the untaught control group. The increased use of modal auxiliary verbs displayed by the experimental group and the decreased use of modal auxiliary verbs displayed by the control group are indicative of the need to have grammar explicitly taught in all the levels of study for students to improve their academic writing skills. The inability of students to write competently in English impacts negatively on their ability to express themselves clearly and precisely in their academic writing. Such a state of affairs threatens their chance towards the securement of better employment in the competitive job market. As alluded to earlier, it has been attained that students' written work is replete with errors of grammar which, arguably, is indicative of the gaps in the student teachers' knowledge on the language forms characterising the English language. This makes an argument for explicit teaching of grammar towards enhancing the communicative linguistic ability of ESL student teachers.

It is thus contended in this article that knowledge of how modal auxiliary verbs function in a sentence has the potential of helping students articulate their ideas precisely and succinctly not only in speaking but also in writing. Moreover, it is evident that most students at the University of Zululand have serious language problems in writing which need to be addressed. The implication thereof is that it is important for ESL teachers to be highly competent in teaching and use of modal auxiliary verbs and other aspects of grammar to address the learners' language deficiencies. It can be argued, therefore, that understanding modal auxiliary verbs within verb phrases, as well as other constituent parts, has the potential of helping students acquire and enhance competitive expressive skills characterised by commendable clarity specifically in writing. It can also be concluded that if students do not know how to use the modal auxiliary verbs and other language structures competently this is likely to result in poor understanding of what is written in the textbooks and what is communicated around their world. Thus, conducting formal grammar classes where apart from the noun phrase, the modal auxiliary verbs within the verb phrase are taught as some of the most critical parts of the complex English structure of a sentence by language teachers is vital towards improving their communicative abilities in their written work.

\section{Implications}

The study holds a number of practical implications for institutional managers such as Deans of Faculties, Heads of Departments, Heads of Schools, for the training with the aim of developing undergraduate students. The study suggests that English grammar should be taught explicitly at all levels particularly in the Faculty of Education to improve the use of Modal Auxiliary Verbs. Lecturers should be supported with necessary professional learning communities to appropriately deliver the modules. This will improve students' academic writing. There should be compulsory English language tutorials in the Faculty where students are taught to write by engaging them in various 
language activities, and lots of academic writing. An interventionist language programme for all students irrespective of their area of specialization should be designed for immediate implementation. The recommended language programme should be diligently monitored for proper implementation to ensure maximum benefits to all students in the Faculty of Education.

\section{References}

Antia, B. E., \& van der Merwe, C. (2019). Speaking with a forked tongue about multilingualism in the language policy of a South African university. Language Policy, 18(3), 407-429. https://doi.org/10.1007/s10993-018-9493-3

Algabe, A. (2009). The English Primary Auxiliary Verbs: A Linguistic Theoretical Exercise. An International Multi-Disciplinary Journal, Ethopia, 3(2). https://doi.org/10.4314/afrrev.v3i2.43606.

Ajani O.A. \& Gamede, B.T. (2020). Challenges of high school learners' transition into universities: a case of a South African rural university, Gender \& Behaviour, 18 (2), 15803 - 15812.

Akmajian, A. (1995). An Introduction to Language and Communication. London: MIT Press.

Alobo, J. O. (2015). The Use of Auxiliary Verbs by Nigeria Certificate in Education (N.C.E.) Students: A Case Study of Federal College of Education (FCE), Kano. An International Journal of Literature, Languages and Linguistics, 13, 172-183.

Baldeh, F. (2001). The Students' Companion to Good English. Rex Charles Publication.

Barnes, L. (2011). English as a global language: An African perspective. Oxford: Oxford University Press.

Biber, D, et al (2002). Student Grammar of Spoken and Written Language. China: Pearson Education Ltd.

Biber, B., Conrad, S., \& Leech, G. (2010). Student Grammar of Spoken and Written English. China. Pearson Education Limited.

Branford, W. (1967). An Introduction to the Principles of the Study of Language. Routlegde \& Kegan Paul Limited.

Coetzee-Van Rooy, S. (2020). South African Englishes. In The Routledge Handbook of World Englishes (pp. 250-264). Routledge. https://doi.org/10.4324/9781003128755-17

Chin, B. A. (2000). The role of grammar in improving students' writing. Sadlier: Oxford.

Chkotua, M. (2012). Foreign Language Learners' Errors and Error Correction in Writing Class. Journal of Education, $1(1), 11-15$.

Cook, W. A. S. J. (1978). Semantic Structure of the English Modals. TESOL Quarterly, 12(1), 5-16. https://doi.org/10.2307/3585786

Cox Jr, T. (1990). Problems with organizational research on race and ethnicity issues. Journal of Applied Behavioral Science, 26(1), 5-23. https://doi.org/10.1177/002188639002600103

Crystal, D. (2011). A dictionary of linguistics and phonetics (Vol. 30). John Wiley \& Sons.

Cummins, S. (1997). Discourse and grammar. In T.A. Dijk (Ed.). Discourse as structure and process. London: Sage.

Ellis, R. (2006). Researching the effects of form-focused instruction on L2 Acquisition. AILA Review, 19(1), 18-41. https://doi.org/10.1075/aila.19.04ell

Ellis, R. (1994). The study of second language acquisition. Oxford: Oxford University Press.

Eyisi, J. C. (2011). A Grammar of English: The Students Companion. Rex Charles Publication.

Fain, J. A. (2004). Reading Understanding and Applying Nursing Research. Second edition. FA Davis. Philadelphia PA.

Ferris, D. (1999). The Case for Grammar Correction in L2 Writing classes: A Response to Truscott 1996. Journal of Second Language Writing, 8(1), 1-11. https://doi.org/10.1016/S1060-3743(99)80110-6

Ferris, D. (2002). Treatment of Error in Second Language Student Writing. Ann Arbor: The University of Michigan Press.

Gibbs, G. (1999). Using Assessment Strategically to Change the Way Student Learn. Assessment Matters in Higher Education, 41.

Green, H. (2014). Use of theoretical and conceptual frameworks in qualitative research. Nurse researcher, 21(6), 
34-38. https://doi.org/10.7748/nr.21.6.34.e1252

Halliday, M. K. (2004). An Introduction to Functional Grammar. Hodder Education.

Holmes, J. (1983). Speaking English with the appropriate degree of conviction in C. Brumfit (ed.). Learning and Teaching Languages for Communication: Applied Linguistics Perspectives. London: CILT.

Horby, A. S. (1974). Oxford advanced learner's dictionary of current English. Oxford. Oxford University press.

Imenda, S. (2014). Is there a conceptual difference between theoretical and conceptual frameworks? Journal of social sciences, 38(2), 185-195. https://doi.org/10.1080/09718923.2014.11893249

Krashen, S. (1987). Principles and practice in second language acquisition. Oxford: Pergamon.

Kroeger, P. R. (2005). Analysing Grammar. New York. Cambridge University Press.

Long, M. (1991). 1991: Focus on form: a design feature in language teaching methodology. In de Bot, K., Ginsberg, R. and Kramsch, C., editors, Foreign language research in cross-cultural perspective, Amsterdam: John Benjamins, 39-52. https://doi.org/10.1075/sibil.2.07lon

Lyster, R., \& Ranta, L. (1997). Corrective feedback and learner uptake: Negotiation of form in communicative classrooms. Studies in Second Language Acquisition, 19, 37-66. https://doi.org/10.1017/S0272263197001034

Maree, K. (2007). First Steps in Research. Pretoria. Van Schaik Publishers.

McLaughlin, B. (1987). Theories of Second Language Learning. London: New York. Edward Arnold.

Moyo, T. (2012). Mother tongues versus an ex-colonial language as media of instruction and the promotion of multilingualism: the South African experience. South African journal of African languages, 22(2), 149-160. https://doi.org/10.1080/02572117.2002.10587506

Moyo, J. (2020). Under preparedness in South African higher education: A limited test of the English Grammar awareness of first-year university students. South African Journal of Higher Education, 34(6), 166-184. https://doi.org/10.20853/34-6-4236

Ngoirinjuguna, J. (2018). The use modal auxiliary verbs in composition writing among standard six pupils of diverse language backgrounds in Nakuru County, Kenya. International Journal of Innovative Research \& Development, 7(1), 88-92. https://doi.org/10.24940/ijird/2018/v7/i1/DEC17094

Oluwole, B. A., \& Rose, J. (1996). Technical and Vocational skills depletion in Nigeria and the need for policy intervention. International Journal of Vocational and Technical Education, 5(6), 100-109.

Palmer, R. (1984). Grammar. London: Longman.

Palmer, R. (2003). Modality in Contemporary English: Theoretical, descriptive and typological issues. Berlin: Mouton de Gruyter.

Parkinson, J. (2001). Explicit Teaching of Grammar and Improvement in the Grammar of Student Writing. Journal of Language Teaching, 35(4), 278-293. https://doi.org/10.4314/tvl.v35i4.53801

Praninskas, J. (1959). English Grammar. USA: Prentice- Hall Inc.

Singh, C. K. R., Singh, A. K. J., Razak, Q. A., \& Ravinthar, T. (2017).Grammar Errors Made by ESL Tertiary Students in Writing. English Language Teaching, 10(5). https://doi.org/10.5539/elt.v10n5p16

Thompson, A. J., \& Martinet, A. V. (1987). Essential Grammar. New York: Oxford University Press.

Truscott, J. (1996). The case against grammar correction in L2 writing classes. Language Learning, 46, 327-369. https://doi.org/10.1111/j.1467-1770.1996.tb01238.x

Umeh, I., \& Anyanwu, E. (2020). The Semantics of Modal Auxiliary Verbs in the 2018 Second Term Inaugural Speech of Governor Willie Obiano in Anambra State. Interdisciplinary Journal of African \& Asian Studies (IJAAS), 6(1).

Wardhaugh, R. (2002). Understanding English Grammar. Australia: Blackwell Publishing.

Wasserman, R. (2019). The historical development of South African English: Semantic features. English in multilingual South Africa: The linguistics of contact and change, 53-72. https://doi.org/10.1017/9781108340892.004

Webb, V. (2004). Using the African languages as media of instruction in South Africa: Stating the case. Language Problems and Language Planning, 28(2), 147-174. https://doi.org/10.1075/lplp.28.2.04web 


\section{Appendix 1}

The Essay Marking Criteria

\begin{tabular}{|c|c|c|}
\hline A. $\mathrm{C}$ & A. B. & C. Stru \\
\hline $\begin{array}{l}\text { Outstanding (25-32): } \\
\text { - Impressive insight into } \\
\text { the topic. } \\
\text { - A well-crafted, almost } \\
\text { flawless presentable } \\
\text { essay. }\end{array}$ & $\begin{array}{l}\text { Outstanding (10-12): } \\
\text { - Choice of words highly } \\
\text { appropriate. } \\
\text { - Virtually grammatical error } \\
\text { free. } \\
\text { - Frequent use of Modal } \\
\text { Auxiliary Verbs. }\end{array}$ & $\begin{array}{l}\text { - Sentences, paragraphs } \\
\text { coherently constructed. } \\
\text { - Length is by the } \\
\text { requirements of the } \\
\text { topic. }\end{array}$ \\
\hline $\begin{array}{l}\text { Adequate (16-24): } \\
\text { - Sound interpretation of } \\
\text { the topic. } \\
\text { - Satisfactory presentation. }\end{array}$ & $\begin{array}{l}\text { Adequate (6-9): } \\
\text { - Choice of words adequate; } \\
\text { - Contains some grammatical } \\
\text { errors. } \\
\text { - Moderate use of Modal } \\
\text { Auxiliary Verbs. }\end{array}$ & $\begin{array}{l}\text { :) } \\
\text { ences, } \\
\text { raphing might be } \\
\text { y in places but still } \\
\text { es sense. Length is } \\
\text { st correct. }\end{array}$ \\
\hline $\begin{array}{l}\text { Elementary (8-12): } \\
\text { - Not always clear, few } \\
\text { ideas, often repetitive. } \\
\text { - Inadequate evidence of } \\
\text { planning, essay not well } \\
\text { presented. }\end{array}$ & 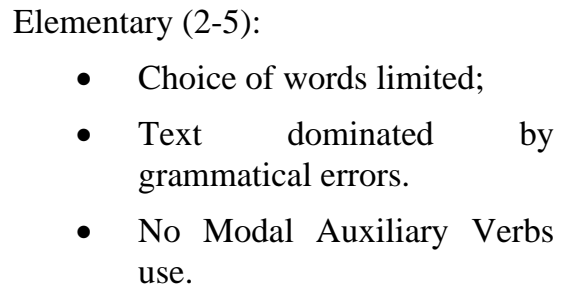 & $\begin{array}{l}\text { Elementary (1-2): } \\
\text { - Sentences, and } \\
\text { paragraphs constructed } \\
\text { at an elementary level. } \\
\text { - Length- too long or } \\
\text { short. }\end{array}$ \\
\hline
\end{tabular}

Total : 50

\section{Copyrights}

Copyright for this article is retained by the author(s), with first publication rights granted to the journal.

This is an open-access article distributed under the terms and conditions of the Creative Commons Attribution license (http://creativecommons.org/licenses/by/4.0/). 